The Muse as I Hear Her 



\section{The Muse as I Hear Her}

Giles Pickford

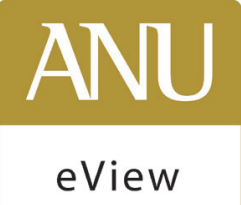




\section{ANU}

eView

Published by ANU eView

The Australian National University

Canberra ACT 0200, Australia

Email: anuepress@anu.edu.au

This title is also available online at http://eview.anu.edu.au

National Library of Australia Cataloguing-in-Publication entry

Author: $\quad$ Pickford, Giles, author.

Title: $\quad$ The muse as I hear her / Giles Pickford.

ISBN: $\quad 9781921934131$ (paperback) 9781921934148 (ebook)

Subjects: $\quad$ Australian poetry.

Dewey Number: A821.4

All rights reserved. No part of this publication may be reproduced, stored in a retrieval system or transmitted in any form or by any means, electronic, mechanical, photocopying or otherwise, without the prior permission of the publisher.

Printed by Griffin Press

All photos from Giles Pickford's private collection except where otherwise indicated

(C) Giles Pickford 2013

This edition (C) 2013 ANU eView 


\section{Contents}

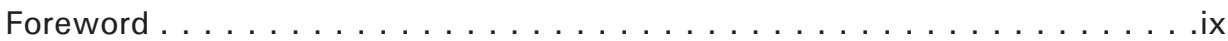

James J. Fox

The Soul . . . . . . . . . . . . . . . . . . 1

Haiku for Eve and Pandora . . . . . . . . . . . . . . . . 2

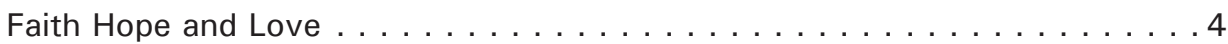

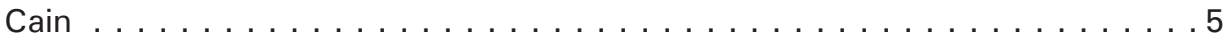

The Snake Replies. . . . . . . . . . . . . . . . . . . . . . . .6

A Handful of Symbols . . . . . . . . . . . . . . . . 7

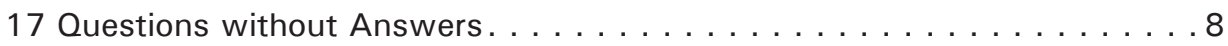

The Ballad of Old Kirrawee . . . . . . . . . . . . . . . . . . 9

A Nonsense Rhyme for a Senseless Time . . . . . . . . . . . . . . 10

On the 3rd Anniversary of the New ACT House of Assembly:

A cartoon in verse . . . . . . . . . . . . . . . . 11

On the Unlikely Possibility that there are First and Last in People . . . . . . . . 13

Seven, Eleven, Nine. . . . . . . . . . . . . . . . . . . . . . . . . . . . . 14

Paroo, Bokhara, Warrego, Irrara . . . . . . . . . . . . . . . 15

Just as Well . . . . . . . . . . . . . . . . . . . . . . . 17

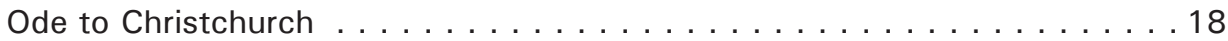

Haiku for Taiwan. . . . . . . . . . . . . . . . . . . . . 19

Diplomatic Incident: Coombs Car Park . . . . . . . . . . . . . . . 20

Leviathan, Ziz and Behemoth . . . . . . . . . . . . . . . 21

Sedition is Curved . . . . . . . . . . . . . . . . . . . . 22

Random Patterns on a Screen . . . . . . . . . . . . . . . . . . . . . . . 23

On the Unlikely Possibility that there are First Causes

in the Universe . . . . . . . . . . . . . . . . . . . . . 24

Things you will never ever know . . . . . . . . . . . . . . . . . 25

Numbers after Heisenberg, 1927 . . . . . . . . . . . . . . . . . . . 26

A Haiku on People who are Always Complaining . . . . . . . . . . . . . . 27

The Angle of Repose . . . . . . . . . . . . . . . . . . . . . . 28

Déjà Prévu (Already Foreseen) . . . . . . . . . . . . . . . . . . . 29

On Our Ruby Wedding Day. . . . . . . . . . . . . . . . . . . 30

About the author. . . . . . . . . . . . . . . . . . . . . . 31 

Dedicated to Polyhymnia: the Muse of Sacred Poetry 



\section{Foreword}

This volume, The Muse as I Hear Her, has been compiled at the urging of ANU Emeritus Faculty. It is intended to honour Giles Pickford, an admired colleague of long standing. Giles was employed at the ANU for ten years. He officially began his appointment in the ANU Public Affairs Division on the 21 st of November 1988 and he retired on the 8th of May 1998. At that time, a group of colleagues had formed an association that was to become the ANU Emeritus Faculty. From 1998 to the end of 2012, Giles was Secretary to the Emeritus Faculty. He served the Emeritus Faculty for a longer period than he was officially employed at ANU. Until recently he continued in the role of Corresponding Secretary, but health intervened at the age of 73. He can no longer drive because of vertigo and so his visits to Canberra have been curtailed.

As members of the Emeritus Faculty, we wanted to honour Giles for his good fellowship and for the many services he rendered to the Faculty. After various discussions, we decided to highlight one of Giles' special interests - his close involvement in the ANU Poets' Lunch.

The Poets' Lunch is an ANU institution that has gone through various incarnations. Begun informally in the 1970s by ANU-based poets such as A. D. Hope, R. F. Brissenden, Geoff Page, Rosemary Dobson and others, this first generation would meet on occasion at the ANU Staff Centre. At these lunches they fashioned poems in praise of wine.

In time this founding generation ceased to gather. In consequence, in 1993, at a celebration in the Great Hall of University House held to honour A. D. Hope, Giles and Colin Plowman were charged with reviving the traditions of the ANU Poets' Lunch. They succeeded and a second generation of lunches began. The scope of these lunches was expanded and Giles became a key participant in this next generation until his retirement in 1998.

Subsequently, a third generation has taken up the traditions of the ANU Poets' Lunch. Gatherings are now held at the Emeritus Faculty. Members of this third generation suggested this volume of Giles' poetry be put together as an appropriate tribute from the ANU Emeritus Faculty. David Walker prepared the compilation and with Giles' assistance, he collected some of the photographs in the volume. Others have come from the ANU Archives.

This volume is thus a token of recognition from friends and colleagues to Giles Pickford - for his multiple contributions to the life of the University and its community.

James J. Fox

Chair, ANU Emeritus Faculty 


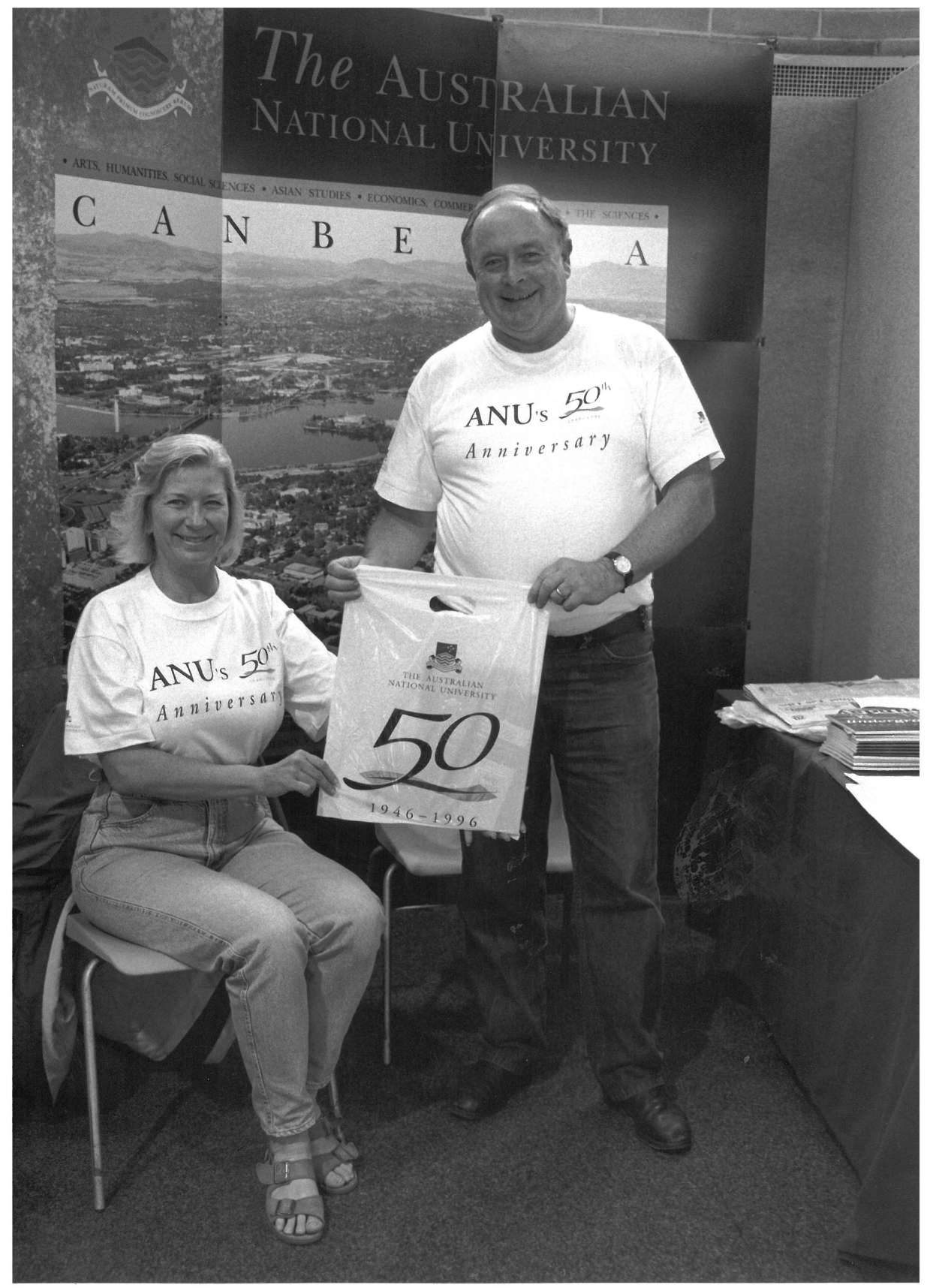

Giles and Jan Eagleton display some of the promotional material for the ANU sesquicentenary 1996

Photo courtesty ANU Archives 


\section{The Soul}

A baby sparrow fell from its nest. I was 6 .

We took it in and fed it with an eyedropper.

We called it Cherub.

It snuggled into my cupped hand

Sleeping with its chin on my thumb

I am now 71 and remember Cherub

It resembles a soul in my mind.

It has no weight, it is hungry and it is helpless.

Thousands don't believe it exists.

But I have held it in my hand and cherished it.

It exists across the entire universe.

It has no weight, it is everywhere and nowhere.

It is hungry and helpless.

Thousands are wrong. It exists.

May 1947 and May 2011 


\section{Haiku for Eve and Pandora}

According to the Torah, the Bible, and the Qur'an, Eve was the first woman created by Yahweh, God, and Allah. According to the Greek Myths, Pandora was the first woman on earth. Both women were set up to take the blame for everything that has ever gone wrong: an idea which is rebarbative in the present age. My mother was born in 1907 and was one of the first feminists. She gave me a point of view which is expressed here.

Eve in the Garden

First woman, primordial one

She the innocent

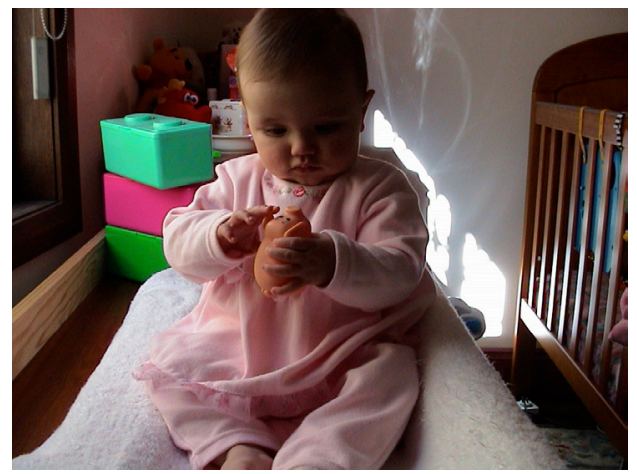

\section{Pandora with three boxes}

Pandora, doomed one

Intellectual enquiry

Curiosity

Pandora and Eve

Spirit of discovery

Both wanting to know 


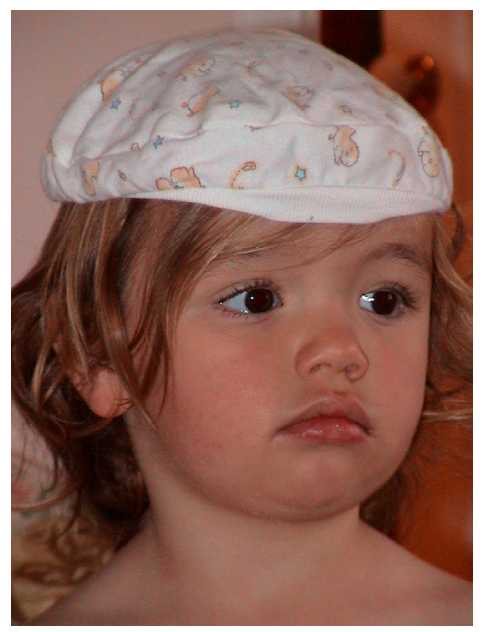

\section{Defiant Eve}

Eve and Pandora

Both born in the human spring

Scapegoats framed for us

Both take all the blame

The evil that from them came

Allocated shame

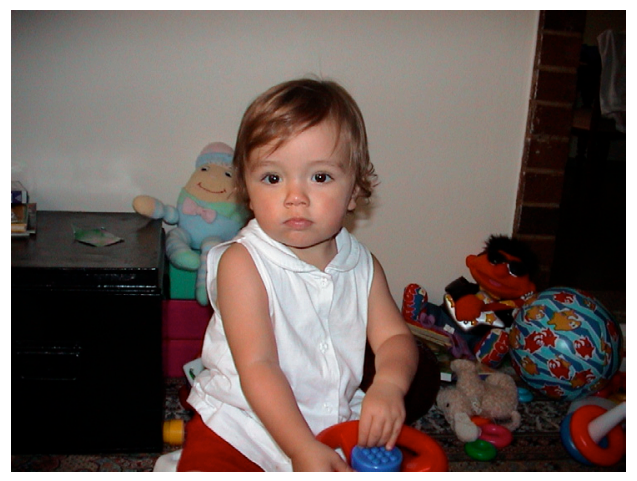

\section{Sad Pandora or Eve}

My wife rails at me

"It's your fault all this went wrong!"

Eve takes her just revenge

Pictures printed with the permission of the Author's granddaughter, Madeline Gass, who is now a charming young woman of nine and likely to take after her great grandmother from what I have seen so far. 


\section{Faith Hope and Love}

There are faith hope and love

Love is the greatest of these.

There are love hope and faith

In faith we face the unknown.

There are hope faith and love

Without all three we're alone.

But hope must be the stone

On which the foundations rest.

Bereft of hope, love and faith

Are birds without a nest. 


\section{Cain}

Born in the first unwanted pregnancy

After the eviction from paradise

Cain arrives with a rock in his hand

To smash the skull of the favoured child

And become the first murderer in the land 


\section{The Snake Replies}

Snakes always speak in blank verse. Rhyming is too far off the ground and it makes them giddy.

$\begin{array}{cc}\text { Me? Cold-blooded? Nonsense! } & \text { III } \\ \text { I am the temperature of my ambience. } & \text { III } \\ \text { I lie on a hot rock and I am } 40 \text { degrees. } & \text { III } \\ \text { The temperature drops and I sleep. } & \text { III } \\ \text { You would die on the rock and freeze at night. } & \text { III } \\ & \text { III } \\ \text { I have no limbs. } & \text { III } \\ \text { And so have no circulatory disorders. } & \text { III } \\ \text { I only need to eat twice a week. } & \text { III } \\ \text { I have only one enemy: you. } & \text { II } \\ & \text { III } \\ \text { YII } \\ \text { You are surrounded by enemies. } \\ \text { III } \\ \text { III } \\ \text { III } \\ \text { II } \\ \text { I neuld }\end{array}$

To be published in the 2013 Poets' Lunch at ANU (theme: Cold-blooded things) 


\section{A Handful of Symbols}

The first finger points and accuses Second is longest: its gesture is obscene The third bears the ring of faithfulness The fourth is prayerful and serene Strong thumb is one and all alone And for ever will oppose them 


\section{Questions without Answers}

Who allows those two addicts to have that bright-eyed unwanted child? Who permits the child's teacher to abuse a position of trust? Did both create the arsonist? And was his hangman duly licensed?

Who licences Scrooge to grind the faces of the poor? By what right does the Warder curtail the liberty of the oppressed?

Who authorises the purblind torturer?

What principle permits the just war?

By what authority does the polyp

make a reef? What guides the rambling vine?

What force informs unravelling history?

What anvil forges the incandescent Tiger?

Is blind nature licensed or unlicensed?

Who licences Poets, who are "the mirrors of the gigantic shadows which futurity casts upon the present"? Was it Shelley? Who licences the giver of licences?

All poets are licensed; but, are some more licentiously licensed than others?

Published in the 2008 ANU Poets' Lunch (theme: Poetic Licence) 


\section{The Ballad of Old Kirrawee}

This is the Ballad of brave Faherty

Who loved a fair maiden in Old Kirrawee

Up on the moors he bended his knee

And offered his troth beneath a green tree

Maeve was her name, her hair was jet black It fell in soft waves all down her sweet back

Her eyes were deep blue, and she had a knack of driving men wild by selling them Smack

A hooker was she, a pusher as well

Poor brave Faherty was going to Hell

When for this wild maiden he stupidly fell

No matter what happened their love didn't jell

Up on the wild moors of Old Kirrawee

He tied a strong rope to the same green tree

Where he'd declared his love on bended knee

Thus ended the life of poor Faherty

Those who pass by the moor are taken aback

By the Ghosts of both lovers up on the track

He with the rope hanging from his poor neck

And she with the blue eyes selling him Smack

Assisted by Bruichladdich Islay Malt

Boxing Day 2007 


\section{A Nonsense Rhyme for a Senseless Time}

The people of Catamite thought

That the Minister ought to do nought

For grinding the cattle

And pounding the pratal

Were all that the good people sought

The Tsunaminous Minister fought

To change all the rules which he thought

Were 'holding us back

And creating a crack

In the Cateconomic Report'

All vassals were turned into clowns

All verbs were changed into nouns

All customs were cancelled

All missions enhancelled

All caps were strategically crowns

The Minister got what he wanted

The fonts were slowly disconted

The cattle ungrounded

The pratal impounded

The Catamites sad and garronted

Although the Catamites mourned

The Minister's face was adorned

On History's fair page

For age after age

While his subject's belongings were pawned

Published in the 2005 ANU Poets' Lunch 


\section{On the 3rd Anniversary of the New ACT House of Assembly: A cartoon in verse}

The Sun came up rosy on that frabjous day When the people's champions gathered for the fray,

Beneath Ethos' statue they sat fumbling, The proud and humble together mumbling, Waiting for Roberta's call to order, Awed, nervous and awkward, dressed nattily, Aware of strife within the border Of Australia's newest Principality.

McRae gave the signal, up they rose, Ritualistically rising on their toes, Whilst the gloomy citizenry, With knotted brows and clasped hands, Wondered if all would be good and well This thought occurred also to Kate Carnell.

Wayne Berry, battle hard and jolly, Victor of the skirmish known as the Visiting Medical Officers Folly Was flanked by his Chief, Rosemary Follett, Champion of the Legislature,

Gentle in look, merciless in nature. Then came Bill Wood and Terry Conolly, Governing town and school lawfully, Solemn and riven by the awful plight Of representing the Centre and the Right. Ellis, Elinor and Lamont then emerge, Walking backwards to protect the rear

Of fledgling Government from the scourge Of Stevenson rumbling in hot pursuit; And Humphries, sad-eyed and hirsute. Then De Domenico, righter than right, Kaine and Westende, walking slowly through the arch Preserving their dignity. Ah! might is trite At the tail-end of a triumphal march. 
Last to join the panoplied processors

Were Szuty and Moore, the town's confessors,

Veterans of the lust industry debate,

Deciders of the dying person's fate,

One barbigerous the other not,

Ending the processional sentence with

The necessary dot.

Arriving a little late, Greg Cornwell,

Deputy Speaker, a man well used

To being terminally confused,

Noticed a vast wraith athwart the theatre.

He recognised in its jovial features

Hector Kinloch, forty feet in stature,

Smiling down upon his fellow creatures

As they entered the newest Legislature.

Published in ANU Poets' Lunch 1996 


\section{On the Unlikely Possibility that there are First and Last in People}

Some people see themselves as first and some as last. But there is no difference. Money distorts their perceptions, acting like a curved mirror.

First will be last

And last will be first

An atom divides

A drink from a thirst

What is the difference

Between tycoon and bum?

One takes Gin, the other Rum

One a loaf, the other, crumb

The rich and the poor

Are joined at the hip

There's interdependence

In the rise and the dip

Wealthy and prisoner

Suffer rigidity

Both have to live in

Gated aridity

Published in the ANU Poets' Lunch, 2007 (Theme: First and Last Things) 


\section{Seven, Eleven, Nine}

We eat and drink each day, for

Hunger obscures the pointless

Repetition of it all.

But there is a thirst from which

The untouched moment arrives.

Unknowable except by

A general assent amongst

The munchers and slurpers

That suddenly they are in

Unexplored Territory

The fog of sameness lifts and

We inhabit a new place.

The voices change and the faces are suffused

With the same light that saw Burke gazing on the Gulf,

Or the wonder of Giles at the western end

Of strata of colour beneath the blue.

This place can also be found solo.

But only out-of-doors when in the

Company of the many eyes that

Watch us when we eat beside the fire:

On the edge of a wild place, alone.

Published in the programme for the 1993 ANU Poets' Lunch. The obscurity of the title lifts when the number of syllables to the line is counted. 


\section{Paroo, Bokhara, Warrego, Irrara}

Green flash of parrots through the gidgee, Red glare of sun off the claypan floor, Cold stars shine, night sounds quiver, fire in the grate at the homestead door.

Dusty-breasted and perilous her loves

On the long rubble of the Yantabulla Road.

Lousy Jacks whoop on the Yellow Box twig While red fox slinks below.

Wild boar roots near twenty-mile drain Out back in the Brigalow.

Loving and dangerous she combs her hair On the long dust of the Yantabulla Road.

Smoke in the eye, dew on the nose, The sun rises slow on the edge of the world. Ring around the Moon, rain on the gilgai, These are the gifts of her love unfurled.

Patient, all-knowing, lonely she waits On the long mud of the Yantabulla Road.

Bleached skull winks and willy willy laughs In the barbed wire heat of the furnace days. Iron lunged wind from the Bulloo overflow Dries blood spit and tears in the noon day haze.

Lose her, and she will never find you

On the long dust of the Yantabulla Road.

Paroo, Bokhara, Warrego, Irrara, On the long straight curve of the Yantabulla Road. 


\section{Bush Glossary}

Gidgee: A type of mulga in the family Acacia

Lousy Jack: A pied Currawong prevalent on the North West Plains of NSW:

Family - Artamidae; Order- Passeriformes

Gilgai: An area of flat ground that is under water when it rains. Try to drive across it then and you will sink to the axles. Walk across and you will sink to the ankles

Willy Willy: A tiny tornado only a foot across which can take your hat off and suck the tea out of your cup if it comes across you in the heat of the day.

Winner of the Traditional Bush Verse section 1990 Binalong Banjo Paterson Poetry Prize 


\section{Just as Well}

It's just as well the sea

Will not rise over me,

Though myriads will flee

Poor Bangladesh and Zyder Zee.

It's just as well the drought

Will not see the winter out

At our resort strewn coast.

But burn wheat farms to toast.

It's just as well pestilence

Will meet with much resistance

From our well fed immunity,

But smite the poor community.

It's just as well the quake

Will not shake us all awake.

Though mothers' hearts may ache

In Bam and Sharm al Sheikh.

It's surely just as well.

But is it just, as well?

Published in the 2004 ANU Poets' Lunch 


\section{Ode to Christchurch}

Christchurch people for day after day

Have suffered shock and grief so bitter

For months they've been shaken like the prey

In the jaws of a grim predator

The Earth heaved and seethed like boiling water

It melted like butter in the sun

There was little unbroken in Bexley

Bromley or Sumner once the quake was done

Their lives can never be the same again

Uncertainty lies beneath the ground

The bonds between women, children and men

Are all that's left which are strong and sound

But like light from a far off beacon

The distant sweetness of hope is found

Christchurch was and will be again

New Zealand's most beautiful town

with Tom Gregg 


\section{Haiku for Taiwan}

1. For Mandy Lin

Taiwan dreams like an opal

Hidden in the China Sea

Beautiful is she.

2. For Professor Pierre Yang

Guns across the Strait we hear

Thunder from the Silent Zone

But can they hear us?

3. For Carlo Chen

Quietly they gather the

Two-leaf tea in Alishan

In a golden bowl

4. For Madame Pao-Chuan Chang

Danshui on the river mouth

History is in your bones

Children take your gift

5. For Stephen Liu

Teeming Taipei bursts with noise

But in the Martyrs' Shrine is

Silence of lost lives

6. For Lian-Cherng Tang

In Towradgi you found me

By the great blue southern sea

My eyes have opened

December 2005, after the Ceremony at the Fort San Domingo Museum, Taiwan 


\section{Diplomatic Incident: Coombs Car Park}

Out back of the Coombs after a Public Lecture

Where Paul Dibb spoke with some conjecture

Of Australia's future defence posture

(Mate, no need to think what it'll cost yer!)

Some Diplomats from the recalcitrant north,

(Near north that is, not north of the fourth

parallel) were convulsed in a clatter of mirth

About the wide open coast of our part of Earth.

Staggering past in the afternoon's last gleam

Your unworthy servant caught on to their theme.

He interjected (forgetting about trade)

With this quarrelsome, undiplomatic tirade.

"Eminences, we Aussies are lacking in fear.

Think, when estimating your likely losses;

Australians would prefer to fight for a year

Than work one day for the bosses." 


\section{Leviathan, Ziz and Behemoth}

The waxing waning wayward moon looks back from the horizon Her shining path sprinkles across the vast gulf of water. Two eyes are shining like arc welders. See, it is Leviathan Glaring back from the edge of the globe intent on slaughter

His bowels house his motive force fed by the yellow rock whose Hideous strength knows no containment. High on his shining back He carries the many manifestations of Ziz: awaiting their cues A buzzing fury of wasps and hornets impatient to attack

On the distant shore the massed herds of Behemoth graze and sleep A dispersed force of a trillion parts driven by one mind Whose piercing eye is aware of what approaches from the deep Whose spies watch every street, whose hidden hands touch every kind.

We sacrificed to them; we gave them our gold and our young ones We poor weak creatures who scurried around their legs fed this fear The feverish nightmare has persisted down through all the aeons Existing now in the massed military demigods of land, sea and air The writer acknowledges the author of The Book of Job 41:1-34 for the inspiration. Published in the ANU Poets' Lunch, 2010 (theme: Yetis, Yowies and Unicorns) 


\section{Sedition is Curved}

The universe is curved and so is endless time.

The Earth's road is curved and all creatures walk this way. There is something in it which hates a dead straight line.

So nature's lovely, curly, random shapes hold sway.

But there is one deadly straight unnatural force Which shows its hatred for the universal curve.

Tyranny drives with great speed in linear course,

Piercing the rib cage of freedom. It does not swerve.

Sedition bows humbly to unnatural power.

Appearing bent, recalcitrant, with curled lip; it would

Resist tyranny at every turn, hour by hour

Until the universal arc of all that's good

Bends arrow, spear, sword, cannon, each linear thing

Into a rounder shape. Thus the great circle of time

Completes its perennial quest, eradicating

Cruellest tyranny, the most unnatural crime.

Published in the ANU Poets' Lunch, 2006 (Theme: Sedition) 


\section{Random Patterns on a Screen}

My darkened computer screen looks back at me, empty.

Droplets from past sneezes are dotted across the dark.

The random pattern they make does tempt me

To see the arrangement of galaxies and stars.

Looking at the random pattern I hit upon a wheeze.

Is the scatter of the far-flung stars

The result of a colossal cosmic sneeze? 


\section{On the Unlikely Possibility that there are First Causes in the Universe}

If something has no end, then can one suppose that it has no beginning?

If there is no beginning

Then ending is done

A circle is endless

Beginning is none

Eternal desire precedes

Cause and effect

It yearns for our love

Which we dare not reject

We are its reflection

It is our perfection

It reaches far back

Before the first night

Before the first light

Before the first sin

A world without end

Has no origin

The second of a pair of poems submitted to the Poets' Lunch at ANU in 2007, on the theme First and Last Things 


\section{Things you will never ever know}

Inspired by Heisenberg's Principle of Uncertainty

The moment you are born and first see your mother

The moment when you die and last see your lover

The moment when sleep shuts the curtains of your mind

These are the moments you will never ever find

Nor will you ever know the nature of time

Nor the depth of space, nor the number nine

The Quark and the Lepton will not be understood

Nor will you comprehend the nature of The Good

Some people know that they are always right

That certainty is real does not cause them fright

But some are relaxed to know it is also true

The sum of one and one is approximately two 


\section{Numbers after Heisenberg, 1927}

A number is an unsteady measure

Heisenberg told us so

Because nothing is still for a second

A snapshot is too slow

Some things move at tectonic speed

Some move faster than light

Accuracy is impossible

When a blur is in your sight

Australia moves north each year

At the rate that toe nails grow

But you set the whole room in a spin

With positional vertigo

That a number can be exact

Is a useful abstraction, but

Multiplication and division

Addition and subtraction

Momentum and position

Are rocks in liquefaction

Published in ANU Poets' Lunch, 2012 (theme: Playing with Numbers) 


\section{A Haiku on People who are Always Complaining}

Man standing still accuses,

But running man excuses.

Man needs momentum. 


\section{The Angle of Repose}

A talus slope achieves the angle of repose

The younger the slope the steeper

The older slope has a much milder incline

Its mildness betrays that it's deeper

It takes a long time to reduce the incline

Memories go back much longer

Not on the move, the rocks rest in their groove

Immobile, they know they are stronger

Young rivers fly like arrows down their slopes

Impatient to rush through the scattered moraine

Old rivers, unhurried, find what they seek

Meandering carefully all over the plain

To live forever is to know more, not less

To arrive there we must be motionless 


\section{Déjà Prévu (Already Foreseen)}

Derelict age with mottled scaly skin

With fading rheumy eyes, limping and thin

Unsteady of stance with balance denied

An open mouth with dribble at the side

Colourless thinning out of falling hair

The day-long occupancy of the chair

Aching joint, gnarled knuckle and tired bone

The vacant stare of one all ways alone

Listless, joyless, poverty-stricken age

With random outbursts of impotent rage

Breathless, toothless, pointless, quiet despair

Prosthetic, pathetic, going nowhere

The musty rancid smell and rattling breath

Marks the long lonely intercept with death

The shimmering view from the mountain peak,

The immensity of past time loved and lost,

Such abundance of memory must speak

From its great fullness. Love won at such cost,

The brawling careless days of long ago,

The sappy happy rambling days of old,

The rise of love and children that follow;

Then that fever called work: which the honest hold

Hard, but is held easy by the hollow.

At last when the harvest is in and done

Debts are paid, children grown, working no more

He moves quietly by the sea in the sun.

He hears the curved waves drumming down the shore

And treasures the beauty while his time is run

Published in ANU Poets' Lunch 2011 (theme: Deja Vu) 


\section{On Our Ruby Wedding Day}

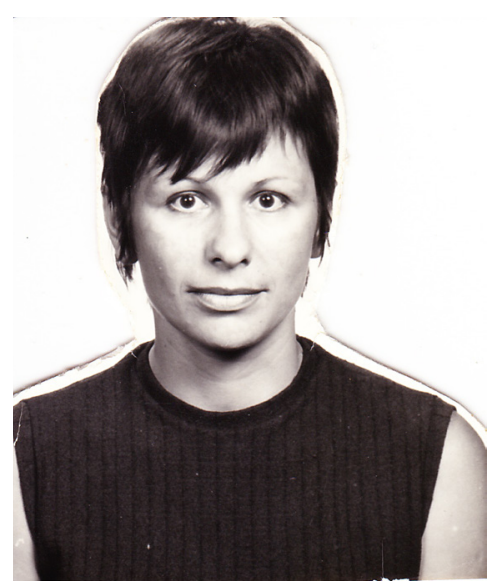

Thank you, dear, for forty years,

For all our joy and all our tears,

For all our children, and all of theirs,

For taking pains and smoothing cares

For forty years I held your head

Against my heart and quietly said

'I love you'. And now I say

'With this Ruby I thee re-wed.

On our 40th Wedding Day.' 


\section{About the author}

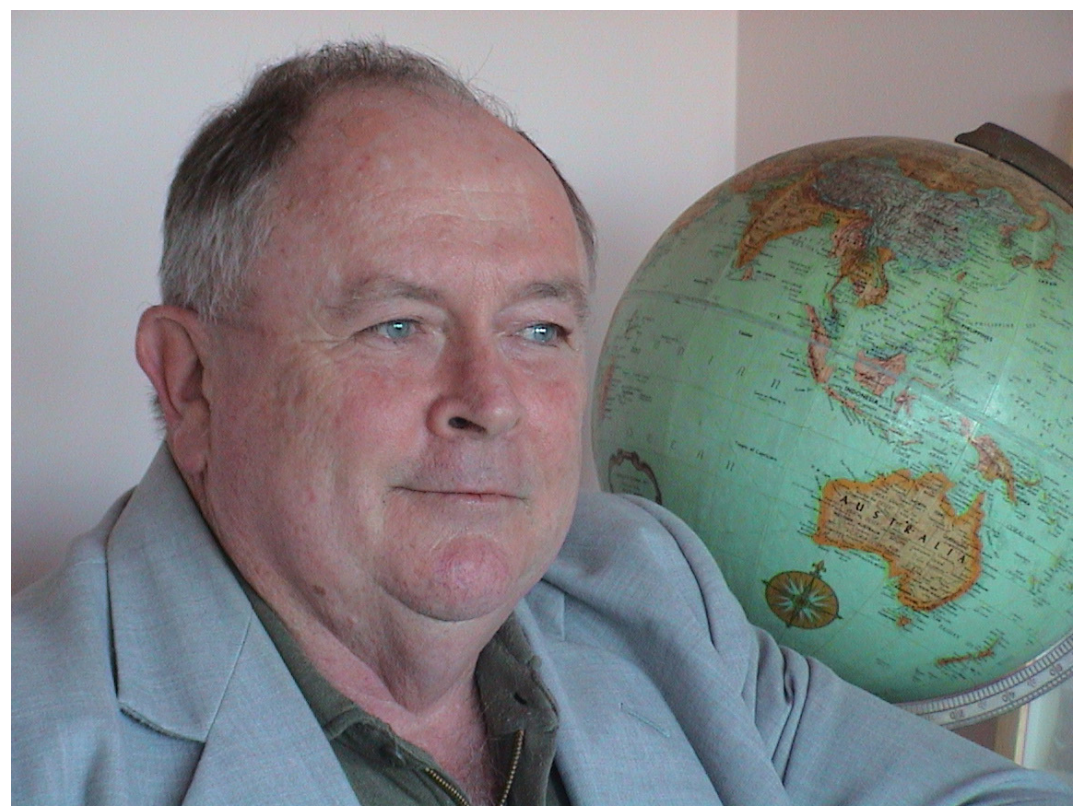

Giles Pickford BA (Hons) was born in Bombay in 1941. However, he spent most of his early years growing up on a farm near Albany, WA. He was educated at Albany High School and the University of Western Australia where he obtained a BA first class Honours degree majoring in English Literature.

After graduation he spent some time in a droving team near Shark Bay, WA, before succumbing to a career as a university administrator, specialising in the fields of event organisation, fund raising and public relations in general.

He has worked at the University of WA, UNE, AVCC, James Cook University, the Australian Cancer Society, the University of Wollongong and The Australian National University.

He served as an Alderman of the Wollongong City Council from 1985-88 and he has served two terms with the ACT Cultural Council from 1991-96. He recently retired as the Secretary of the ANU Emeritus Faculty, and Convenor of the ATEM Ghosts: both of them are organisations for retired people.

He worked until the age of 71, much of it in later years as a volunteer.

He wrote poems, mostly in later life, which he published on his own web site. He has been an active member of the various incarnations of the ANU Poets' Lunch: http://www.anu.edu.au/emeritus/poets/

This publication of his poems was undertaken by the Poets' Lunch at ANU assisted by the ANU Emeritus Faculty. 